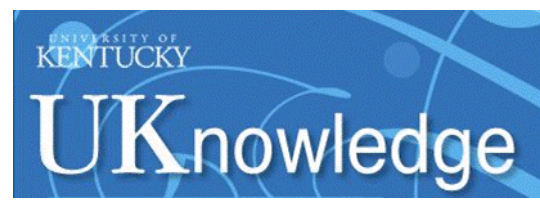

University of Kentucky

UKnowledge

\title{
Association Between Chronic Liver and Colon Inflammation During the Development of Murine Syngeneic Graft-Versus-Host Disease
}

\author{
Jason Anthony Brandon \\ University of Kentucky, jabran2@email.uky.edu \\ Jacqueline Perez-Rodriguez \\ University of Kentucky, jprjackie@yahoo.com \\ C. Darrell Jennings \\ University of Kentucky, cdjenn@email.uky.edu \\ Donald A. Cohen \\ University of Kentucky, don.cohen@uky.edu
}

Vishal J. Sindhava

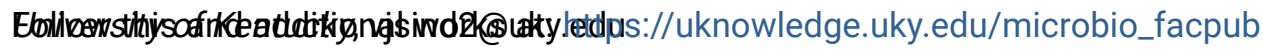

Part of the Gastroenterology Commons, Medical Immunology Commons, Medical Microbiology

Semmext pagelofulaldiforetigenthommons, and the Physiology Commons

Right click to open a feedback form in a new tab to let us know how this document benefits you.

\section{Repository Citation}

Brandon, Jason Anthony; Perez-Rodriguez, Jacqueline; Jennings, C. Darrell; Cohen, Donald A.; Sindhava, Vishal J.; Bondada, Subbarao; Kaplan, Alan M.; and Bryson, J. Scott, "Association Between Chronic Liver and Colon Inflammation During the Development of Murine Syngeneic Graft-Versus-Host Disease" (2010). Microbiology, Immunology, and Molecular Genetics Faculty Publications. 125.

https://uknowledge.uky.edu/microbio_facpub/125

This Article is brought to you for free and open access by the Microbiology, Immunology, and Molecular Genetics at UKnowledge. It has been accepted for inclusion in Microbiology, Immunology, and Molecular Genetics Faculty Publications by an authorized administrator of UKnowledge. For more information, please contact UKnowledge@lsv.uky.edu. 


\section{Association Between Chronic Liver and Colon Inflammation During the Development of Murine Syngeneic Graft-Versus-Host Disease}

Digital Object Identifier (DOI)

https://doi.org/10.1152/ajpgi.00511.2009

Notes/Citation Information

Published in American Journal of Physiology: Gastrointestinal and Liver Physiology, v. 299, issue 3, p. G602-G613.

Copyright $@ 2010$ by the American Physiological Society

The copyright holder has granted the permission for posting the article here.

The document available for download is the authors' post-peer-review final draft of the article.

Authors

Jason Anthony Brandon, Jacqueline Perez-Rodriguez, C. Darrell Jennings, Donald A. Cohen, Vishal J. Sindhava, Subbarao Bondada, Alan M. Kaplan, and J. Scott Bryson 
1 Association between chronic liver and colon inflammation during the development of

2 murine syngeneic graft-versus-host disease.

3

4

5 J. Anthony Brandon ${ }^{1,4}$, Jacqueline Perez ${ }^{5}$, C. Darrell Jennings ${ }^{2}$, Donald A. Cohen ${ }^{1,5}$,

6 V.J. Sindhava1 , S. Bondada ${ }^{1,4}$, Alan M. Kaplan ${ }^{1,4,5}$ and J. Scott Bryson ${ }^{1,3,4,5}$.

7

$8 \quad{ }^{1}$ Department of Microbiology Immunology and Molecular Genetics, ${ }^{2}$ Pathology, ${ }^{3}$ Internal

9 Medicine, ${ }^{4}$ Markey Cancer Center and ${ }^{5}$ Graduate Center for Toxicology, University of

10 Kentucky Medical Center, Lexington, KY, 40536

11

12 Running Head: IBD-associated chronic liver inflammation.

15 Contact information: Dr. J. Scott Bryson, Department of Internal Medicine, Division of

16 Hematology, Oncology and Blood \& Marrow Transplantation, 108B Combs Cancer

17 Research Building, University of Kentucky, 800 Rose Street, Lexington, Kentucky

1840536.

19

20 Email: jsbrys@.uky.edu

21

22 
The murine model of cyclosporine A (CsA)-induced syngeneic graft-versus-host disease (SGVHD) is a bone marrow transplantation (BMT) model that develops chronic colon inflammation identical to other murine models of $\mathrm{CD} 4^{+} \mathrm{T}$ cell-mediated colitis. Interestingly, SGVHD animals develop chronic liver lesions that are similar to the early peribiliary inflammatory stages of clinical chronic liver disease which is frequently associated with inflammatory bowel disease (IBD). Therefore, studies were initiated to investigate the chronic liver inflammation that develops in the SGVHD model. To induce SGVHD, mice were lethally irradiated, reconstituted with syngeneic BM and treated with CsA. All of the SGVHD animals that developed colitis also develop chronic liver inflammation. Liver samples from control and SGVHD animals were monitored for tissue pathology, RNA for inflammatory mediators and phenotypic analysis and in vitro reactivity of the inflammatory infiltrate. Diseased animals developed lesions of intraand extrahepatic bile ducts. Elevated levels of mRNA for molecules associated with chronic liver inflammation including mucosal cellular adhesion molecule -1 , the chemokines CCL25, CCL28, CCR9 and $T_{H} 1$ and $T_{H} 17$ associated cytokines were observed in livers of SGVHD mice. $\mathrm{CD}^{+} \mathrm{T}$ cells were localized to the peribiliary region of the livers of diseased animals and an enhanced proliferative response of liver associated mononuclear cells against colonic bacterial antigens was observed. The murine model of SGVHD colitis may be a valuable tool to study the entero-hepatic linkage between chronic colon inflammation and inflammatory liver disease. 
47 KEY WORDS: chronic liver inflammation, inflammatory bowel disease, $T_{H} 1$ immunity, $48 \quad T_{H} 17$ immunity,

49

50 
51

52

\section{INTRODUCTION}

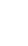

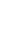

Clinically a high percentage of IBD patients also present with some form of portal/periportal liver inflammation including autoimmune hepatitis $(\mathrm{AlH})$, primary sclerosing cholangitis (PSC) and occasionally primary biliary cirrhosis (PBC) (30). In a recent study, elevation of serum aminotransferase was found in one third of 500 IBD patients (39). Primary sclerosing cholangitis and AlH are common extraintestinal manifestations of IBD, with the majority of PSC patients having IBD (>75\%); ulcerative colitis is present in most ( 90\%), with Crohn's Disease being present in the rest $(5,17)$. While PSC is typically diagnosed after the diagnosis of IBD, the diagnosis of PSC can precede IBD by several years (30). Autoimmune hepatitis is a more classic autoimmune disease but some patients can be diagnosed with features of both PSC and $\mathrm{AIH}$ as an overlap disorder. These forms of chronic liver disease are characterized by portal/periportal inflammation that can lead to fibrosis.

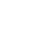

6

IBD-associated chronic liver inflammation such as PSC appears to be mediated by IFN-y-producing, microbial-antigen-specific $\mathrm{CD}^{+} \mathrm{T}$ cells activated in the gut and recruited to the liver by aberrant expression of mucosal addressin cellular adhesion molecule 1 (MAdCAM-1) and chemokines (CCL25) that are typically expressed in the gut (reviewed (1)). Upregulation of these molecules on the portal endothelium of the liver enables the recruitment of $\alpha 4 \beta 7^{+}, \mathrm{CCR} 9^{+}, \mathrm{CD}^{+}$memory $\mathrm{T}$ cells to the liver from the gut (1). $\alpha 4 \beta 7$ and CCR9 are the ligands for MAdCAM and CCL25, respectively. It 
has been postulated that Toll-like receptors (TLR) on immune (macrophages, Kuppfer cells, dendritic cells (DC)) and non-immune cells (cholangiocytes) in the liver are exposed to bacteria/bacterial products via entero-hepatic circulation and bind pathogenassociated molecular patterns (PAMPs), become activated and secrete proinflammatory cytokines and chemokines (TNF- $\alpha$, IL-1 $\beta$, IL-6; CCL25) (42) that can participate in the recruitment of adaptive immune cells to the liver (28).

(1)

\section{Animal models have been developed to understand the pathophysiology} associated with chronic liver inflammation. One class utilizes bacterial wall components and develop biliary sclerosis after bacterial overgrowth of the small bowel (35) or following injection of bacterial products and induction of experimental colitis in rats and rabbits (36). Non-suppurative destructive cholangitis is the main lesion during murine allogeneic GVHD (58). The injection of 2,4,6-trinitrobenzene sulphonic acid (TNBS) into the extra-hepatic bile duct induces an antigen-specific immune response that is similar to PSC clinically, including a $\mathrm{CD}^{+} \mathrm{T}_{\mathrm{H}} 1$ immune response with stricturing of hepatic bile ducts and induction of portal fibrosis (43). In addition to models of PSC, other murine models have been developed to simulate $\mathrm{AlH}$. The intravenous injection of conconavilin A (32) or the injection of antigen-specific T cells into transgenic mice that express novel antigen on the surface of hepatocytes results in the development of $\mathrm{T}$ cell mediated $\mathrm{AlH}$ (11). More recently PBC was shown to develop in IL-2Ra ${ }^{-/-}$animals. In this model the $\mathrm{CD}^{+}$effector cells differentiated in the liver and appeared not to be recruited from other sites (59). 
Inflammatory bowel disease represents a chronic inflammation of the intestinal

97 tract of unknown origin. It has been recognized that IBD results from a dysregulated immunological response to commensal bacteria in genetically susceptible individuals (48). Experimentally, colitis develops in chemically treated and gene knockout animals, and following adoptive transfer of naïve $\mathrm{CD} 4^{+} \mathrm{T}$ cells into immune deficient recipients (reviewed (49)). The majority of these models have been thought to develop as a result of a $T_{H} 1$ cytokine-based immune response that is characterized by excessive production of IL-12/IFN- $\gamma /$ TNF- $\alpha$. Recently, however, it has been shown that in addition to $T_{H} 1$ cells, a distinct population of IL-17-producing CD4 ${ }^{+} T$ cells $\left(T_{H} 17\right.$ cells) can drive intestinal inflammation (reviewed (23)).

In murine SGVHD a colitis-like disease developed following lethal irradiation, syngeneic BMT and a short course of CsA therapy $(7,18,19)$. Clinical symptoms (weight loss, diarrhea) typically occurred in $80-100 \%$ of the CsA-treated animals, with lymphocytic infiltration of the colon and liver being observed. In vivo depletion and adoptive transfer studies demonstrated that $\mathrm{CD} 4^{+}$, but not $\mathrm{CD} 8+\mathrm{T}$ cells played a prominent role in the development of murine SGVHD-associated colitis $(6,10)$. Similar to murine colitis models, recent studies have demonstrated enhanced responsiveness of SGVHD CD4 ${ }^{+} \mathrm{T}$ cells against antigens isolated from cecal bacterial preparations (6), leading to the speculation that $\mathrm{CD} 4^{+} \mathrm{T}$ cells reactive against bacterial antigens mediate the chronic intestinal and liver inflammation observed during murine SGVHD. 
119 inflammation. In this manuscript, data is presented that demonstrates an absolute

120 linkage between liver inflammation and colitis in the SGVHD model and test the

121 hypothesis that microbial-specific T cells migrate from the colon to the liver to induce

122 chronic liver inflammation. Chronic liver inflammation of intrahepatic/extrahepatic bile

123 ducts was associated with the aberrant expression of colon-associated

$124 \mathrm{CAM} /$ chemokines and a $\mathrm{T}_{\mathrm{H}} 1 / \mathrm{T}_{\mathrm{H}} 17$ inflammatory immune response. Given the complete

125 entero-hepatic linkage, the role of $\mathrm{CD}^{+} \mathrm{T}$ cells in the SGVHD disease model and the

126 similarity in inflammatory response/lesions with the early lesions associated with clinical

127 PSC, murine SGVHD is a useful model in which to study the immune mechanisms that

128 are essential for the initiation and maintenance of chronic liver inflammation during IBD. 


\section{MATERIALS and METHODS}

Animals. Female $\mathrm{C} 3 \mathrm{H} / \mathrm{HeN}$ mice were purchased from Harlan (Indianapolis, IN) at 19-21 days of age and were used within 1 week of arrival. Animals were housed in sterile microisolator cages (Lab Products, Maywood, NJ) and were fed autoclaved food and acidified water ad libitum. All animal protocols were approved by the University of Kentucky Institutional Animal Care and Use Committee.

Induction of SGVHD. Bone marrow (BM) was isolated from the femurs and tibias of syngeneic age matched mice. Donor BM suspensions were prepared in RPMI 1640 (Cellgro, Herndon, VA) containing $100 \mathrm{U} / \mathrm{ml}$ penicillin and $100 \mu \mathrm{g} / \mathrm{ml}$ streptomycin and 2 $\mathrm{mM}$ glutamine (GIBCO, Grand Island, NY) and depleted of Thy $-1^{+} \mathrm{BM}$ cells as previously described (8). To induce SGVHD, recipient mice were lethally irradiated (900 cGy) in a Mark I ${ }^{137}$ Cs irradiator (J.L. Shepherd and Associates, Glendale, CA). Following irradiation, the animals were reconstituted i.v. with $5 \times 10^{6}$ syngeneic T cell depleted BM (ATBM) cells, 4-6 $\mathrm{h}$ after conditioning. Beginning on the day of BMT, the mice were treated daily i.p. for 21 days with $15 \mathrm{mg} / \mathrm{kg} /$ day of CsA or the diluent olive oil (Sigma-Aldrich, St. Louis, MO). Upon cessation of CsA therapy, the BMT control and CsA-treated animals were weighed 3 times per week and monitored for the development of clinical symptoms of SGVHD (weight loss, diarrhea). Animals that developed clinical symptoms for three consecutive weighings were considered positive for the induction of SGVHD. 
163 euthanized animals at the indicated times after BMT and cessation of CsA therapy and

164 placed into $10 \%$ buffered formalin. The fixed tissues were embedded in paraffin, cut

165 into 4-6 $\mu \mathrm{m}$ sections, mounted onto glass slides and stained with a standard H\&E

166 protocol. All slides were analyzed blindly and were graded for inflammation according

167 to a previously published grading scale (9).

Immunohistochemical Staining. Liver samples were taken and immediately embedded in Tissue-Tek Optimal Cutting Temperature (O.C.T.) Compound (Sakura

171 Finetek, Torrance CA) and frozen in liquid nitrogen. Samples were then cut into 10- $\mu \mathrm{m}$

172 tissue sections, mounted on glass slides and stored in $-20^{\circ} \mathrm{C}$ freezer. Tissues were fixed

173 with $3 \%$ paraformaldehyde for 15 minutes followed by $3 \times 5$ minute washes in PBS.

174 Slides were blocked to prevent non-specific binding with $2 \mathrm{mg} / \mathrm{ml}$ normal donkey serum

175 (Jackson ImmunoResearch, West Grove, PA), 0.3\% Triton X-100 in PBS for 30 minutes $176 \quad 4^{\circ} \mathrm{C}$. Slides were then incubated with FITC-conjugated mAb against CD4 (GK1.5; BD 177 PharMingen, San Diego, CA) (1:1000) in PBS supplemented with 2 mg/ml normal 178 donkey serum and $0.3 \%$ Triton $\mathrm{X}-100$ at $4^{\circ} \mathrm{C}$ overnight in a humidified chamber. Control 179 staining was performed by using FITC IgG Rat antibody (1:1000). After 2 washes in 180 PBS, the samples were visualized on a Carl Zeiss microscope 100x magnification and 181 digitized with the camera AxioVision HR. Because the automatic exposure setting on 182 the microscope camera overcompensated for tissues without T cell infiltration, post183 capture image processing was used to adjust tissue section images to the equivalent 184 levels of background fluorescence. 
Quantification of Serum Markers. Serum/plasma ALT concentrations were performed as per manufactures instructions. Briefly $100 \mu \mathrm{l}$ of serum was mixed with $1 \mathrm{ml}$ of $37^{\circ} \mathrm{C}$ prewarmed ALT (SGPT) reagent (Pointe Scientific, Canton, MI, USA) and further incubated at $37^{\circ} \mathrm{C}$ for 1 minute before the absorbance at $340 \mathrm{~nm}$ was read. An additional 2 absorbance readings $(340 \mathrm{~nm})$ were taken 1 minute apart with the sample being incubated at $37^{\circ} \mathrm{C}$ between readings. The ALT concentration (IU/L) was calculated by multiplying the average absorbance difference per minute ( $\Delta \mathrm{abs} / \mathrm{min}$.) by the factor 1768.

Levels of anti-ssDNA in the serum/plasma of SGVHD mice were determined by ELISA. Briefly, wells of a 96-well plate were coated with $100 \mu$ of ssDNA (heat denatured salmon sperm DNA at $10 \mu \mathrm{g} / \mathrm{ml}$ in citrate phosphate buffer, $\mathrm{pH}$ 5.0). The plates were incubated at $4^{\circ} \mathrm{C}$ overnight. After washing the plates were washed $2 \mathrm{X}$ with tris-buffered saline containing 0.3\% Tween-20 (TBS-T ( $\mathrm{pH} 7.6)$ ). Plates were blocked with 1.0\% BSA in TBS for 1 hour at room temperature. Plates were washed with TBS-T and experimental samples were diluted $1 / 20$ in TBS-T containing $0.25 \%$ BSA and $100 \mu \mathrm{l}$ were added per well for 2 hours at room temperature. (The standard positive control was pooled serum from $\left(3 \mathrm{H} 9 \times \mathrm{CD}^{-1-}\right) \mathrm{F} 1$ mice at different dilutions (4)). Plates were washed with TBS-T and alkaline phosphatase-conjugated goat anti-mouse Ig (heavy and light chain), diluted $1 / 1000$ in TBS-T with $0.25 \%$ BSA was added to each well for 2 hours at room temperature. Plates were washed with TBS-T and $2 X$ with TBS. $p-$ nitrophenyl phosphate (pNPP) was diluted to $1 \mathrm{mg} / \mathrm{ml}$ in substrate buffer (Phenylamine 
buffer, $\mathrm{pH}$ 9.8) and added to each well for 30 minutes at room temperature and the absorbance was read at $405 \mathrm{~nm}$.

Detection of perinuclear anti-neutrophil cytoplasmic antibodies (p-ANCA) was performed on ethanol fixed human neutrophil substrate slides (INOVA Diagnostics, San Diego, CA). Substrate slides were placed in a humidified chamber and 20 ul of either sample serum/plasma, positive or negative controls (INOVA Diagnostics) was added to the corresponding wells and incubated for 30 minutes at room temperature. Slides were then washed twice in PBS. Mouse IgG anti-bodies were detected by FITC-conjugated goat anti-mouse IgG antibodies (Sigma, St. Louis, MO) or goat anti-human IgG antibodies for positive controls (Sigma). After 30 minute incubation the slides were washed twice in PBS and analyzed using a Carl Zeiss microscope at 200x magnification and digitized with the camera AxioVision HR. The grading of the p-ANCA results was determined by the level of fluorescence as described by the manufacturer. Depending on the intensity of the staining the sample was given a fluorescent grade. Intensity grading criteria for fluorescence is as follows; brilliant fluorescent staining of nucleus (grade 4), bright fluorescent staining of nucleus (grade 3), nuclear staining clearly distinguishable, but not bright green (grade 2), lowest specific fluorescence that allows the differentiation of the nucleus from the background staining (grade 1), no distinction between the nucleus and background staining (grade 0). For this study a sample that had been graded 2 to 4 was considered positive and those samples graded either 0 or 1 were considered negative for $\mathrm{p}-\mathrm{ANCA}$. 
232 isolated from the livers using Trizol reagent (Invitrogen, Grand Island, NY). mRNA (1

$233 \mu \mathrm{g})$ from each group was reverse-transcribed into cDNA using the Promega (Madison,

$234 \mathrm{WI})$ reverse transcription system. cDNA was suspended in $1 \mathrm{x}$ master mix $(0.5 \mathrm{U}$

235 Platinum Taq (Invitrogen), $0.2 \mathrm{nM}$ of each dNTP, $0.2 \mathrm{mM}$ PCR buffer (Idaho

236 Technology, Inc., Salt Lake City, UT), 1x SYBR green (Molecular Probes, Eugene, OR).

237 The reaction volume was made to $10 \mu \mathrm{l}$ with $\mathrm{dd} \mathrm{H}_{2} 0$. Primers for IL-12, IFN- $\gamma, \mathrm{TNF}-\alpha$

238 (21), IL-17, IL-23p19, CCR9, CCL25, CCL28, MAdCAM-1 and GADPH (44) were

239 purchased from Integrated DNA Technologies (Coralville, IA) and were used at $1 \mu \mathrm{M}$

240 concentration. Real-time PCR was performed on a Roche Lightcycler (Roche

241 Diagnostics, Indianapolis, IN). Reaction conditions were as follows: 1 min at $95^{\circ} \mathrm{C}$

242 followed by 50 cycles of 6 s at $95^{\circ} \mathrm{C}, 10 \mathrm{~s}$ at $60^{\circ} \mathrm{C}$ and $15 \mathrm{~s}$ at $72^{\circ} \mathrm{C}$. All the primers listed

243 were normalized to GADPH and their expression calculated by the comparative $\mathrm{C}_{\mathrm{T}}$

244 method. control BMT or SGVHD mice at 2-4 weeks after cessation of CsA therapy and perfused with $5 \mathrm{ml}$ digestion buffer (RPMI 1640, 5\% FCS, 0.05\% collagenase IV (Sigma), 0.002\%

249 DNAse I (Sigma-Aldrich) then single cell suspensions were prepared in digestion buffer.

250 The liver homogenate was placed into $50 \mathrm{ml}$ centrifuge tubes and placed in a $37^{0} \mathrm{C}$ 251 water bath for 40 min with intermittent shaking. The cells were washed twice and the 252 pellet was resuspended in $32 \%$ Percoll and centrifuged for $20 \mathrm{~min}$ at $2000 \mathrm{rpm}$ at room 253 temperature. The pellet was treated with $0.83 \%$ Tris-buffered $\mathrm{NH}_{4} \mathrm{Cl}$ to remove RBC. 254 After washing the cells were placed into 10\% complete RPMI (10\% FCS, $100 \mathrm{U} / \mathrm{ml}$ 
255

256

257

258

259

260

261

262

263

264

265

266

267

268

269

270

271

272

273

274

275

276

277

278

penicillin and $100 \mu \mathrm{g} / \mathrm{ml}$ streptomycin and $2 \mathrm{mM}$ glutamine, $5 \times 10^{-5} \mathrm{M}$ of $2-\mathrm{ME}$ ) for use in in vitro proliferation assay and flow cytometric analysis.

Proliferation Assay. A cecal bacterial antigen (CeAg) preparation was prepared according the procedure described by Cong et al (13). Bone marrow-derived dendritic cells (DC) were generated by culturing C3H/HeN BM cells in RPMI 1640 containing 5\% FCS, penicillin/streptomycin/glutamine, and $5 \mathrm{mM}$ 2-ME containing $20 \mathrm{ng} / \mathrm{ml}$ of recombinant murine GM-CSF. The non-adherent cells were removed on days 3 and 5 and GM-CSF containing media was added. At 8-10 days after initiation of culture, cecal antigen-pulsed DC were prepared by incubation of DC over night with $200 \mathrm{mg} / \mathrm{ml}$ of CeAg (6). This dose of CeAg was the minimal dose required to induce maximal proliferative response of $\mathrm{CD}^{+} \mathrm{T}$ cells from SGVHD animals. Furthermore, incubation of the $\mathrm{DC}$ with CeAg resulted in the maturation of $\mathrm{DC}$ resulting in increased expression of MHC class II and B7 costimulatory molecules (J.S. Bryson, unpublished observation). To determine the proliferative capacity of LAM against bacterial antigens, $2 \times 10^{5}$ LAM from control or SGVHD mice were cultured with $1 \times 10^{4}$ irradiated (2000 cGy) DC or CeAg -pulsed DC in a 96 well flat bottomed plate. Proliferation was measured by the addition of $\left[{ }^{3} \mathrm{H}\right]$-thymidine during the last $18 \mathrm{~h}$ of a $96 \mathrm{~h}$ culture. containing $1 \% \mathrm{FBS}, 0.1 \% \mathrm{NaN}_{3}$ ). To minimize non-specific staining, cells were incubated with Ab against CD16/CD32 (2.4G2, Fc Block ${ }^{\circledR}$, BD PharMingen). The cells were stained with antibodies against CD4 (RM-4-5) (Caltag, Burlingame, CA), CD8 (CTCD8, Caltag), CD11b (M1/70), CD11c (BD PharMingen), TLR2 (eBioscience, San 
279 Diego, CA) or TLR5 (Imgenex, San Diego, CA) then analyzed by flow cytometry. To 280 detect invariant natural killer T cells (iNKT), LAM were stained with $\alpha \beta T C R(H 57-597$ 281 (BD PharMingen)) and $\alpha-$ GalCer loaded CD1 tetramers or unloaded CD1 tetramers 282 (kindly provided by Dr Mitch Kronenberg, La Jolla Institute for Allergy and Immunology, 283 San Diego, CA)(38). To determine intracellular cytokine production isolated LAM were 284 placed in complete RPMI growth media and stimulated with anti-mouse CD3 ascites for 2858 hours at $37^{\circ} \mathrm{C} .2 \mu \mathrm{M}$ monensin (eBioscience) was added during the last 4 hours of 286 culture and the cells were harvested, counted and placed in staining buffer (PBS 287 containing $1 \% \mathrm{FCS}, 0.1 \% \mathrm{NaN}_{3}$ ). To reduce nonspecific staining, cells were incubated 288 with $\mathrm{Ab}$ against CD16/CD32 (Fc Block). $1 \times 10^{6}$ cells were then stained with 289 fluorochrome-conjugated mAb against CD4 (Caltag Burlingame CA). Intracellular 290 staining for IL-17, IFN- $\gamma$ and TNF- $\alpha$ was performed using an Intracellular Cytokine 291 Staining Kit (eBioscience, San Diego, CA) according to manufacturer's directions. 292 Stained cells were analyzed using a BD Biosciences FACSCalibur flow cytometer (San 293 Jose, CA).

296 using Student's $t$ test. Differences $\leq 0.05$ were considered statistically different. 


\section{RESULTS}

Chronic Liver Pathology Associated with SGVHD. In addition to CD4 ${ }^{+}$T cellmediated inflammation in the epithelium and lamina propria of the colon (Fig. 1B vs $1 \mathrm{~A})(8,10)$ with similarity to that observed in other models of murine colitis, significant and reproducible chronic inflammatory lesions are observed in the livers of SGVHD mice. As opposed to other murine models of colitis where chronic liver inflammation was observed in $\sim 30 \%$ of the animals (40), histological analysis of both the colons and livers of SGVHD mice showed an absolute correlation between colitis and liver inflammation (9/9 in the current study). As shown in Figure 1, the inflammation described for samples taken in the first 2-4 weeks (Fig. 1D) after induction of SGVHD resembles the initial portal stage of clinical PSC, with inflammation limited to the portal area with no fibrosis being present (50). The lesions demonstrated significant portal lymphoid infiltrates in and around the intra-hepatic bile ducts with cholangiocyte necrosis (Fig. 1D). Liver samples taken at 8 weeks after cessation of CsA therapy (Fig. 1E (H\&E) and 1F (Trichrome)) show extension beyond the limiting plate, resembling the periportal stage (II) of PSC (50). In contrast, an occasional lymphocyte can be observed outside the bile ducts of transplant control animals (Fig.1C) with no significant inflammatory response being observed. Examination of the extrahepatic bile ducts taken from the SGVHD animals showed apoptotic changes along with the bile duct invasion by inflammatory cells (Fig $1 \mathrm{H})$. Inflammatory debris was also present in the lumen as well as inflammatory cells being located in the surrounding adventitia. Minimal inflammation was detected in the extrahepatic bile ducts isolated from the control BMT animals (Fig 1G). As shown previously (9), a significantly higher pathology 
322 grade was observed in the colon and livers obtained from the SGVHD vs BMT control

323 animals (Fig. 2). Although slightly reduced in severity, similar changes and pathology

324 grades were observed 1 week after cessation of CsA therapy, prior to clinical symptoms

325 of SGVHD (J.S. Bryson, unpublished observations).

elevated levels of ALT were observed in the serum/plasma from SGVHD versus control BMT animals (Fig. 3A left panel). These increases were associated with the liver pathology observed in these animals (Fig. 1,2) and were significantly elevated in SGVHD mice. Similar to the increased presence of liver enzymes, significantly increased levels of the autoantibody, anti-ssDNA (Fig 3B left panel), and importantly, perinuclear ANCA ( $\mathrm{p}-\mathrm{ANCA}$ ), was observed during active disease as well ( $92 \%$ vs 10\%)(Fig. $3 \mathrm{C}$ left panel). No differences in the levels of ALT, anti-ssDNA or p-ANCA autoantibodies were observed between control and CsA-treated animals one week after cessation of CsA therapy. However, the levels of these mediators increased with time

337 after cessation until they were significantly increased by 5-6 weeks after induction 338 therapy (Fig. 3 A-C right panels). Changes in ALT and p-ANCA have been associated 339 with the development of chronic liver and colon inflammation including AIH and PSC $340(52,54,61)$.

Phenotypic Analysis of LAM Isolated from SGVHD Animals. In addition to studies monitoring pathology and liver-associated inflammatory markers, preliminary studies 344 were initiated to monitor phenotypic changes that occur in the cellular immune response in the SGVHD liver. Liver associated mononuclear cells were isolated from transplant 
control and SGVHD mice and monitored for the presence of CD4 ${ }^{+}, \mathrm{CD}^{+}, \mathrm{NKT}$ cells,

347 macrophages and neutrophils. No significant change was observed in CD4 ${ }^{+}, \mathrm{CD}^{+}{ }^{+}$Fig

348 4A) and neutrophils (J. Bryson, unpublished observations) between BMT controls and

349 SGVHD animals. However, while the number of $\mathrm{CD}^{+} \mathrm{T}$ cells did not change,

350 immunohistochemistry analysis showed that $\mathrm{CD}^{+} \mathrm{T}$ cells were primarily localized

351 around the hepatic bile duct in the SGVHD liver (Fig 4D; arrows) compared to being

352 more diffusely dispersed thought the BMT control liver (Fig 4C). In addition, while no

353 apparent changes in T cell numbers were observed in the SGVHD liver, a significantly

354 decreased proportion of iNKT cells staining with a-GalCer-CD1d tetramers, in LAM from

355 BMT control vs SGVHD mice (Fig 4E). These cells have been shown to be involved in

356 development of oral tolerance $(29,57)$ and increase in SGVHD mice that recover from

357 colitis ( $-30 \%$ of diseased animals) (J. Bryson, unpublished observations). Finally,

358 significantly increased percentages of $\mathrm{CD}_{11 \mathrm{~b}^{+}}$(Fig. 4F) or CD11 $\mathrm{b}^{+} \mathrm{GR}-1^{-}$

359 myeloid/macrophage cells were observed in LAM from SGVHD vs control animals. As

360 activation of innate effector cells via signaling through Toll-Like Receptors (TLR) may

361 play a significant role in the generation of adaptive immunity and more pointedly in the

362 initial stages of PCS pathology (53), increases in macrophages may be significant in the

363 development in SGVHD-associated liver inflammation.

TLR Expression in SGVHD. Gram positive and Gram negative bacteria were

366 found in a significantly higher percentage of the livers from CsA-treated versus control

367 animals (18). As bacteria are a significant source of TLR ligands (Pathogen-associated

368 molecular patterns (PAMPs)) it is likely that liver macrophages (Kupffer cells) and other 369 tissue cells come into contact with PAMPs resulting in activation and secretion of 
inflammatory mediators. Real time PCR studies demonstrated that mRNA for all TLRs (1-9) was increased in the liver and colon of SGVHD mice. Importantly, mRNA for four of the five TLR's that are associated with binding bacterial PAMPs, TLR-1 (J. Bryson, unpublished observations), 2, 5 and 9, were significantly increased (Supplementary Data, Fig. 1). Finally, while antibodies are not available for all TLR, flow cytometry studies were performed using antibodies against TLR-2 and TLR5 to determine the nature of the LAM cells expressing these TLR. A significant increase in TLR2 and 5 staining was found in $\mathrm{CD} 11 \mathrm{~b}^{+}$cells isolated from the livers of SGVHD versus control BMT animals (Supplementary Data, Fig. 2).

Increased Inflammatory Mediators in Livers of SGVHD Mice. It has been widely suggested that IBD-associated chronic liver inflammation is mediated by $T_{H} 1 C D 4^{+} T$ cells (42). Initial studies demonstrated that SGVHD-mediated colon inflammation could be mediated by $T_{H} 17$ or $T_{H} 1$ immune responses (Brandon et al. Development of a $T_{H} 17$ immune response during the induction of murine syngeneic graft-versus-host disease, Submitted for publication). To determine the nature of the $T$ helper immune response in the SGVHD liver, LAM were isolated from control and diseased animals, stimulated and analyzed for the production of IL-17 $\left(T_{H} 17\right)$ or IFN- $Y\left(T_{H} 1\right)$ by intracellular cytokine staining techniques. As shown in Figure 5A, significantly increased percentages of both IL-17- and IFN- $y$-producing CD4 ${ }^{+} \mathrm{T}$ cells were observed in LAM isolated from SGVHD versus control animals. To support and expand these findings, mRNA was isolated from control and SGVHD livers and analyzed by real time PCR for $T_{H} 17$ and $T_{H} 1$ cytokines and inflammatory mediators that are associated with mucosal/liver inflammation. In the SGVHD liver there was a significant increase in mRNA for IFN-y 
$(p=0.0009)$ as previously published in this model (19) and as demonstrated clinically

(42). Since $T_{H} 17$ cells have been shown to be elevated in $\operatorname{IBD}(20,27)$ and in the SGVHD liver (Fig 5A), we sought to monitor the levels of $T_{H} 17$-associated cytokines.

397 Real time PCR analysis of liver RNA demonstrated increased expression of mRNA for IL-17 ( $p=0.0075)$, IL-23p19 and TNF- $\alpha$ (Fig 5B). In addition, increased mRNA for IL12p40 (Fig 5B), a subunit for both IL-23 and the TH1 cytokine IL-12 was found to be 400 significantly increased in diseased livers as well. Finally inflammatory chemokines and chemokine receptors involved in mucosal T cell homing (CCL25, CCL28 and CCR9) (Fig 6 A, B and D) were also increased in the livers of SGVHD mice compared to control animals. The increase in the expression of mRNA for CCR9 was also associated with a significant increase in the expression of CD4 ${ }^{+}$LAM expression CCR9 (Fig. 4B) isolated 405 406 liver of PSC patients $(1,16)$ was also significantly elevated in the SGVHD liver (Fig 6B). A corresponding increase $(p=0.0557)$ in the percentage of $C D 4^{+}$expressing the ligand for MAdCAM, $\beta 7$ integrin, was observed in the LAM from diseased versus control animals (Fig. 4B). Thus, there was an increase in $\mathrm{CD}^{+} \mathrm{T}$ cells in the SGVHD liver that have a phenotype typical of effector cells that are derived in the intestinal tract.

We have observed that at the end of the CsA therapy (d21 post-BMT), prior to 414 the development of clinical symptoms, there are increases in the expression levels of 415 mRNA for proinflammatory cytokines, chemokines and adhesion molecules in the 416 colons of SGVHD animals (Perez et al. Accumulation of CD4 ${ }^{+} \mathrm{T}$ cells in the colon of 417 CsA-treated mice following myeloablative conditioning and bone marrow 
transplantation. Submitted for publication). It is proposed that during PSC, CD4 ${ }^{+} \mathrm{T}$ cells migrate to the liver following activation in the colon via aberrant hepatic expression of MAdCAM and CCL25 (1)(Fig. 6). To investigate when T cells migrate into the liver of CsA-treated animals, liver tissue isolated from CsA-treated/SGVHD and control animals at 14, 21 and 37 days after BMT was stained for $\mathrm{CD} 4^{+} \mathrm{T}$ cells. $\mathrm{CD} 4^{+} \mathrm{T}$ cells were rarely observed in livers from control or CsA-treated animals at 14 and 21 days after BMT (Fig. 7A). Conversely, $\mathrm{CD} 4^{+} \mathrm{T}$ cells were easily detected around the bile ducts (arrow) of diseased animals ( 37 days or 2-3 wks post-CsA) as was shown in Figure 7A. Furthermore, based on PCR analysis, MAdCAM mRNA was not elevated at day 14 post-BMT (J. Bryson, unpublished observations) and both MAdCAM and CCL25 trended towards increased levels in the liver of CsA-treated mice by day 21 post-BMT (Fig. 7B). Together, these findings suggest that an ordered expression of chemokines and CAM results in the timed migration of $\mathrm{CD} 4^{+} \mathrm{T}$ cells into the liver.

\section{LAM from SGVHD Mice Display Increased Microbial Reactivity. Previous studies} have demonstrated increased proliferation of peripheral SGVHD CD4 ${ }^{+} \mathrm{T}$ cells against bacterial antigens (6). Since it is known that increased bacteria were present in the livers of CsA treated animals (18), studies were performed to analyze the anti-bacterial antigen-specific proliferation of LAM isolated from SGVHD mice. LAM isolated from the livers of SGVHD mice demonstrated a significantly enhanced proliferative response against cecal bacterial antigens compared to control liver cells ( $p=0.0002)$ (Fig.8). 


8

\section{DISCUSSION}

Chronic inflammatory processes of the liver are frequently associated with IBD (30). The current study describes the pathogenesis of chronic liver lesions that develop during the induction of murine SGVHD. Murine SGVHD is a unique model of colon inflammation with $100 \%$ penetrance of chronic liver inflammation that involves intra- and extrahepatic bile ducts. SGVHD-mediated liver disease was associated with increased ALT and p-ANCA levels similar to clinical markers of chronic liver inflammation. Liver mRNA levels of molecules associated with chronic inflammation and lymphocyte migration were increased along with $T_{H} 1$ and $T_{H} 17$-associated immune responses. Finally, increased reactivity of hepatic LAM to colonic bacterial antigen- pulsed DC's was observed suggesting that in SGVHD, microbial antigen-specific T cells may be responsible for the chronic inflammation that is observed in the liver. The utilization of murine SGVHD provides an opportunity to study the immune responses involved in both the initiation and progression of IBD-associated chronic liver inflammation.

It has been suggested that the lymphocytic infiltration that is seen in IBDassociated liver inflammation is comprised of cells that were activated within the gut and have migrated to the liver, aided by the aberrant expression of gut homing molecules (1). Studies in the SGVHD model have shown that colon CAM expression is elevated during CsA-therapy as early as day 14 post-BMT and $\mathrm{CD}^{+} \mathrm{T}$ cells begin to accumulate in the colon at this time as well. (Perez et al. Accumulation of $\mathrm{CD}^{+} \mathrm{T}$ cells in the colon of CsA-treated mice following myeloablative conditioning and bone marrow transplantation. Submitted for publication)(10). While the basis for this early induction 
of CAMs and T cell accumulation in the colon is not known at this time, we hypothesize that pretransplant radiation and CsA treatment in the early post BMT period result in the production of inflammatory mediators including TNF- $\alpha$. At least two possibilities exist to explain the early proinflammatory response that occurs during the induction of SGVHD.

First, both radiation and CsA have been shown to induce oxidative stress and transcription factors $(14,51,60,64)$ that could mediate the upregulation of inflammatory cytokines $(12,25,34,63)$. In addition to direct involvement in the production of inflammatory mediators, irradiation and CsA have been shown to damage the gut leading to increased leakage of bacteria (18). The interaction of TLR on innate effector cells with microbial products (PAMPs) is an alternative pathway that could focus the enhanced production of proinflammatory cytokines such as TNF- $\alpha$ within the colon, leading to increased expression of CAM and in accumulation of $\mathrm{CD} 4^{+} \mathrm{T}$ cells in the colons of CsA-BMT animals. Why the expression of these molecules is delayed in the liver, is not clear at this time, but may relate to differences in the effects of the inductive therapy on the target organs. Based on real time PCR data, MAdCAM-1 mRNA was not elevated at day 14 post-BMT, but along with the chemokine, CCL25, trended towards increased levels in the livers of CsA-treated mice by day 21 post-BMT (Fig.7). Few, if any, $\mathrm{CD}^{+} \mathrm{T}$ cells were observed in the livers in the early post-transplant period (days 14 or 21)(Fig. 7), but were observed during active disease (Figs.4, 7).

Phenotypically, increased numbers of $\mathrm{CD}^{+} \mathrm{T}$ cells expressing markers of intestinalderived T cells, $\beta 7$ integrin and CCR9, were found in the livers of SGVHD animals when compared to controls. Together, these findings suggest $\mathrm{CD} 4^{+}$effector cells are activated in the intestinal tract and that an ordered migration of $\mathrm{CD} 4^{+} \mathrm{T}$ cells from the colon into the liver of SGVHD animals exists. 
Hepatic T lymphocytes found in IBD-associated liver inflammation express the

$492 \mathrm{CCR}^{+} \alpha_{4} \beta_{7}{ }^{+}$phenotype classically seen in lymphocytes that have been activated by gut

493 DC's (2). Abnormal expression of the mucosal addressin, MAdCAM-1, along with the 494 gut-associated chemokine CCL25 has been observed at elevated levels in the liver 495 endothelium in PSC $(1,26)$ and provided a mechanism by which CCR9 ${ }^{+} \mathrm{T}$ cells 496 activated in the intestinal tract can migrate to the liver. The mechanisms by which these 497 inflammatory molecules are upregulated in the liver are unknown but may involve the 498 activation of TLR ligands with microbial PAMPS that arrive in the liver via entero-hepatic 499 circulation resulting in the production of inflammatory mediators. Levels of TLR mRNA 500 that bind bacterial PAMPS, as well as TLR-expressing myeloid LAM were elevated in 501 livers from SGVHD animals (Supplementary Fig. 1, 2). This is supported further by 502 previous data demonstrating that increased numbers of bacteria can be detected in the 503 livers of CsA treated mice during the induction of SGVHD (18). Furthermore, similar to 504 peripheral effector cells from diseased animals (6), the LAM's isolated from SGVHD 505 mice demonstrated an increased proliferative response to bacterial antigen-pulsed APC. 506 We have previously shown that isolated $\mathrm{CD}^{+} \mathrm{T}$ cells from the peripheral lymphoid 507 tissues of SGVHD mice could adoptively transfer colitis and liver inflammation into 508 secondary recipient animals (6). The ability of LAM isolated from the livers of SGVHD 509 mice to transfer disease to secondary recipient animals has yet to be determined. 512 be mediated by $\mathrm{T}_{H} 1, \mathrm{CD} 4^{+}$, IFN- $\mathrm{y}$-producing $\mathrm{T}$ cells. Hepatocellular damage through 513 IFN- $\gamma$ is thought to occur by a variety of mechanisms including direct cellular injury, 
514 modulation of Ag presentation, and both the recruitment and activation of other immune

515 cells $(15,55)$. However, the immune phenotype of the cells that induce autoimmune 516 chronic liver inflammation has come into question, with $T_{H} 17$ immunity being observed 517 as well $(22,45)$. Data presented here indicates that $T_{H} 17$ cells, determined by 518 increased intracellular cytokine production of IL-17 by CD4 ${ }^{+}$LAM and increased mRNA 519 levels of $T_{H} 17$ associated cytokines (IL-17, IL-23p19, TNF- $\alpha$ ), were increased in the 520 livers of SGVHD mice. We have also found a significant increase in $T_{H} 17$ associated 521 cytokines in the colons of SGVHD mice (Brandon et al. Development of a $T_{H} 17$ immune 522 response during the induction of murine syngeneic graft-versus-host disease, Submitted 523 for publication). This increase was observed even at day 21 post BMT in CsA-treated 524 mice suggesting that $T_{H} 17$ T cells may have an important role in SGVHD-associated 525 colitis. As increased percentages of $C D 4^{+} T_{H} 1$ were also found in diseased livers, the 526 role that $\mathrm{T}_{H} 17$ and $\mathrm{T}_{H} 1 \mathrm{CD}^{+} \mathrm{T}$ cells play during SGVHD-induced chronic liver 527 inflammation remains to be determined. It should be noted that while $T_{H} 17$ cells are 528 present in the PBC livers of IL-2Ra ${ }^{-/-}$animals, a model of chronic liver inflammation, the 529 data suggests that the IL-17 secreting cells differentiate in the liver and appear not to be 530 recruited from other sites (33), with no enterohepatic linkage being observed in the 531 development of the autoimmune PBC. Finally, both $T_{H} 17$ and $T_{H} 1$ cells have both been 532 detected in an autoimmune model of skin inflammation. These cells developed with 533 different kinetics with $T_{H} 17$ cells emerging early, being replaced by a $T_{H} 1 C D 4^{+}$immune 534 response later in the disease process (37).

535 It is likely that altered immune regulation in the periphery and in the liver following 536 induction of SGVHD contributes to the development of the chronic inflammatory 
responses described in the current manuscript. $\mathrm{CD} 4^{+}$regulatory $\mathrm{T}$ cells have been shown to regulate the development of spontaneous and inducible murine colitis (3). Hess et al. have demonstrated that altered regulatory $T$ cell activity contributed to the development of rat SGVHD with reduced numbers of regulatory lymphocytes being observed in diseased animals (24). Similarly, in a model of CsA-induced autoimmunity, it was shown that reconstitution of $\mathrm{CD} 4^{+} \mathrm{CD} 25^{+}$regulatory $\mathrm{T}$ cells was delayed until after cessation of CsA treatment (62). With these findings in mind we have demonstrated that at the time of cessation of CsA therapy, significantly reduced numbers of $\mathrm{CD}^{+} \mathrm{CD} 25^{+} \mathrm{FoxP}^{+} \mathrm{T}$ cells are present in the spleen and MLN of CsA-treated animals (J.S. Bryson, unpublished observations). Similar to the reduced expression of regulatory T cells in the SGVHD animal, results presented in the current manuscript demonstrated that another T cell population with regulatory potential, iNKT cells, was significantly reduced in the livers of SGVHD versus control BMT animals (Fig. 4E). Invariant NKT cells in the mouse express a single invariant $\mathrm{V} \alpha \mathrm{TCR}$ chain (Vo14Ja18) (reviewed (31)), are positively selected to the nonclassical MHC molecule CD1d, have strong reactivity to the glycosphingolipid $\alpha$-galactosylceramide ( $\alpha$-GalCer) and are present in high numbers in the liver. Liver iNKT cells have been shown to participate in the induction of oral tolerance $(29,57)$, tolerance to antigens in privileged sites $(47)$ and inhibit the development of experimental colitis in mice $(41,46,56)$. Significant reductions in $\mathrm{CD}^{+}$Treg and iNKT are observed in the periphery and livers of SGVHD animals respectively. Thus, as a result of CsA therapy, reconstitution of these important regulatory immune populations is delayed and uncontrolled expansion of T effector cells occurs resulting in the development of chronic colon and ultimately, liver inflammation. In line with this hypothesis, we have demonstrated that recovery from SGVHD (approx. 
$56130 \%$ of diseased animals) is associated with increases in regulatory T cells and iNKT

562 cells and that $\mathrm{CD} 4^{+} \mathrm{CD} 25^{+}$regulatory $\mathrm{T}$ cells from normal mice inhibited the adoptive

563 transfer of SGVHD ((6) J. S. Bryson, unpublished observations) demonstrating the

564 potential role of these cells in controlling chronic inflammation in this model system.

565 In other murine models of colitis the development of chronic liver inflammation

566 was only observed in approximately $30 \%$ of mice (40). Significant and reproducible

567 inflammatory liver lesions of bile ducts was observed in 100\% of SGVHD mice in

568 association with increased inflammatory mediators within the liver that are normally

569 associated with colitis. Furthermore, significant changes in inflammatory markers

570 associated with chronic liver inflammation were observed, suggesting a mechanistic

571 relationship between the development of SGVHD- induced liver inflammation and that

572 observed in the early stages of clinical disease. Similarities include the induction of

573 inflammatory molecules that result in the influx of $\mathrm{CCR9}^{+} \beta 7$ integrin $^{+} \mathrm{CD}^{+} \mathrm{T}$ cells and

574 inflammation of the intra and extrahepatic bile ducts. And while the model mimics many

575 aspects of the disease process associated with clinical chronic liver inflammation, at the

576 time points analyzed thus far, little to no sclerosis has been observed. Whether this is a

577 limitation of the model or merely a timing issue in relation to disease induction remains

578 to be elucidated. With the enterohepatic linkage and the previously published role of

$579 \mathrm{CD}^{+} \mathrm{T}$ cells in the SGVHD model $(6,10)$, the inflammatory response seen in these

580 animals may provide an opportunity to study the pathobiology involved in both the

581 initiation and progression of IBD-associated, chronic liver inflammation. 
583 GRANTS

584

585 This work was supported by National Institutes of Health Grant PO1 CA092372 (J.S.B.).

586

587 
589 Figure 1.

590 Histological examination of SGVHD livers showed development of chronic liver 591 inflammation during murine SGVHD. To induce SGVHD C3H/HeN mice were lethally

592 irradiated, reconstituted with syngeneic BM and treated daily for 21 days with CsA $593(15 \mathrm{mg} / \mathrm{kg} /$ day $)$ or the diluent olive oil. Tissues were taken when animals exhibited 594 clinical symptoms (weight loss, diarrhea) of SGVHD-induced colitis (2-4 or 8 weeks 595 post-CsA). (A) Control colon (H\&E) demonstrating normal histology. (B) Colon from 596 SGVHD animal (H\&E) showing transmural inflammation with apoptotic cells, glandular 597 invasion, crypt abscess formation and complete glandular destruction. Liver tissue from 598 SGVHD animals (8 weeks post CsA) showing portal inflammation (D)(H\&E) with focal 599 extension beyond the limiting plate $(\mathrm{E})(\mathrm{H} \& \mathrm{E}),(\mathrm{F})($ Trichrome) arrows. Transplant control 600 liver (C)(H\&E). Extra-hepatic bile ducts were isolated from control and SGVHD animals 6013 weeks post CsA therapy. Control (G)(H\&E) samples demonstrated mild surrounding 602 inflammation of the common and branching bile duct. Samples of extra-hepatic bile 603 ducts from SGVHD mice $(H)(H \& E)$ showed apoptotic changes in bile duct epithelium 604 (small arrow) and invasion of bile duct epithelium by inflammatory cells in the common 605 duct and branches. Inflammatory debris was present in the lumen and inflammatory 606 cells in the surrounding adventitia. All tissues were photographed at 200X 607 magnification. 
611 Figure 2.

612 Increased colon and liver pathology associated with induction of SGVHD. Pathology

613 grading of tissues was performed (9). Data represents mean grade \pm SEM of samples

614 from 2 experiments $(n=9)$ and significance was determined using the unpaired Student's

615 t test.

616

$617 \quad$ Figure 3.

618 Markers of chronic liver inflammation associated with SGVHD. Serum/plasma was

619 isolated from BMT control or SGVHD mice 3-6 weeks after cessation of CsA therapy

620 during active disease. Levels of $\operatorname{ALT}(A)$, anti-ssDNA (B) and p-ANCA (C) were

621 determined as described in Methods. Left panels represent pooled data, mean \pm SEM

622 from 3 experiments collected at 2-6 weeks post CsA therapy. The data presented in

623 right panels represents time course at time points after cessation of induction therapy

624 ( $n=$ number of samples analyzed). Significance was determined using unpaired

625 Student's t test, or Fisher's exact test, p-ANCA right panel.

626

$627 \quad$ Figure 4.

628 Increased $C D 4^{+} T$ cell localization around the hepatic bile ducts in SGVHD livers. Liver 629 associated mononuclear cells (LAM) were isolated from BMT control and SGVHD mice 630 2-4 weeks after cessation of CsA therapy. The percentage of CD4 ${ }^{+}$and $\mathrm{CD}^{+} \mathrm{T}$ cells

631 (data from 5 pooled experiments) $(A)$, percentage of CD4+ LAM that are $\beta 7$ integrin+ or

$632 \mathrm{CCR} 9+(\mathrm{B})\left(\mathrm{n}=4\right.$ animals), iNKT ( $\alpha-$ GalCer CD1 ${ }^{+}$tetramer) (data from 3 pooled

633 experiments normal $n=2$, control $n=3$ and $C s A n=6)(E)$ and $\operatorname{CD}_{11} b^{+}(F)$ (data from 4

634 pooled experiments) were determined by FACS analysis. Liver sections from transplant 
635

636

637

638

639

640

641

642

643

644

645

646

647

648

649

650

651

652

$653 \quad$ Figure 6.

654 Increased levels of liver inflammatory chemokines and adhesion molecules in SGVHD

655 livers. Hepatic mRNA was extracted from SGVHD mice and cDNA prepared.

656 Inflammatory chemokine and adhesion molecule mRNA was analyzed using real time

657 RT-PCR for the primers CCL25, CCL28 CCR9 and MAdCAM-1. Expression of these

658 genes was normalized to GAPDH using the $\triangle \triangle \mathrm{CT}$ method. Represents pooled data 
659 from 3 experiments, n=12 per group with significance determined using unpaired 660 Student's t test.

661

662 Figure 7.

$663 \mathrm{CD}^{+} T$ cells migrate to the liver after cessation of CsA therapy. Livers were isolated at 66414,21 and 37 days from SGVHD and control animals and analyzed (A) by 665 immunohistochemistry for the presence of $\mathrm{CD}^{+} \mathrm{T}$ cells or $(\mathrm{B})$ for MAdCAM mRNA 21 666 days after BMT by real time RT-PCR. Data presented representative of (A) 4 tissues 667 from two experiments, $(B)$ or pooled samples (mean \pm SEM) from two experiments, $n=8$ 668 and were analyzed using unpaired Student's t test.

669

$670 \quad$ Figure 8.

671 LAM from SGVHD livers showed an increase proliferative response to CeAg-pulsed DC.

672 Liver associated mononuclear cells (LAM) were isolated from BMT control and SGVHD 673 mice four weeks after cessation of CsA therapy. Proliferation against CeAg-pulsed DC 674 in the presence or absence of anti-CD4 mAb was measured by thymidine incorporation 675 during the last 18 to $96 \mathrm{~h}$ assay. Data comparing CeAg-induced proliferation 676 representative of 3 experiments and represents mean \pm SEM of triplicate samples and 677 significance was determined using unpaired Student's t test. CD4 blocking represents 678 results from a single experiment. *Different from control LAM stimulated with DC-CeAg $679 p=0.0209 .{ }^{* *}$ Different from SGVHD DC-Ag $p=0.0231$ 


\section{Supplemental Figure 1.}

685 SGVHD mice showed increased liver TLR mRNA. SGVHD was induced as described. 686 At 2-4 weeks post-CsA mice were euthanized and their livers removed. Hepatic mRNA 687 was extracted and cDNA prepared. Samples were analyzed using real time RT-PCR 688 for the primers TLR 2,4,5 \& 9 (A-D respectively) and the expression of these genes was 689 normalized to GAPDH using the $\triangle \triangle \mathrm{CT}$ method. Represents pooled data from 3 690 experiments, $\mathrm{n}=12$ per group and significance was determined using unpaired Student's 691 t test.

692

\section{Supplemental Figure 2.}

694 Increased TLR expression in LAM isolated from SGVHD. LAM were isolated from 2-4 695 weeks post-CsA therapy from 2-4 control and SGVHD animals and pooled within each 696 treatment group. The cells were stained for the surface and intracellular expression of 697 CD11b and TLR2 and TLR5. RAW264.7 cells were utilized as positive control for TLR 698 staining and were positive for TLR2. A. Representative flow diagrams for staining of 699 TLR2 and TLR5. B. Pooled results from three experiments analyzing expression of 700 TLR2 and TLR5 in LAM from control and SGVHD mice. Significance determined using 701 unpaired Student's t test. 
707 1. Adams DH, and Eksteen B. Aberrant homing of mucosal T cells and extra708 intestinal manifestations of inflammatory bowel disease. Nat Rev Immunol 6: 244$709 \quad 251,2006$.

710 2. Agace WW. Tissue-tropic effector T cells: generation and targeting 711 opportunities. Nat Rev Immuno/ 6: 682-692, 2006.

712 3. Asseman C, Fowler S, and Powrie F. Control of experimental inflammatory 713 bowel disease by regulatory T cells. Am J Respir Crit Care Med 162: S185-189., 7142000.

715 4. Bondada S, Bikah G, Robertson DA, and Sen G. Role of CD5 in growth 716 regulation of B-1 cells. Curr Top Microbiol Immunol 252: 141-149, 2000.

717 5. Broome U, Olsson R, Loof L, Bodemar G, Hultcrantz R, Danielsson A, Prytz 718 H, Sandberg-Gertzen H, Wallerstedt S, and Lindberg G. Natural history and 719 prognostic factors in $\mathbf{3 0 5}$ Swedish patients with primary sclerosing cholangitis. 720 Gut 38: 610-615, 1996.

721 6. Bryson JS, Jennings CD, Brandon JA, Perez J, Caywood BE, and Kaplan 722 AM. Adoptive transfer of murine syngeneic graft-vs.-host disease by CD4+ T cells. 723 J Leukoc Biol 82: 1393-1400, 2007.

724 7. Bryson JS, Jennings CD, Caywood BE, and Kaplan AM. Induction of a 725 syngeneic graft-versus-host disease-like syndrome in DBA/2 mice.

726 Transplantation 48: 1042-1047., 1989. 
8. Bryson JS, Jennings CD, Caywood BE, and Kaplan AM. Thy1+ bone marrow cells regulate the induction of murine syngeneic graft-versus-host disease. Transplantation 56: 941-945, 1993.

9. Bryson JS, Jennings CD, Lowery DM, Carlson SL, Pflugh DL, Caywood BE, and Kaplan AM. Rejection of an MHC class II negative tumor following induction of murine syngeneic graft-versus-host disease. Bone Marrow Transplant 23: 363372, 1999.

10. Bryson JS, Zhang L, Goes SW, Jennings CD, Caywood BE, Carlson SL, and Kaplan AM. CD4+ T cells mediate murine syngeneic graft-versus-host diseaseassociated colitis. J Immunol 172: 679-687, 2004.

11. Buxbaum J, Qian P, Allen PM, and Peters MG. Hepatitis resulting from liverspecific expression and recognition of self-antigen. J Autoimmun 31: 208-215, 2008.

12. Chung BH, Li C, Sun BK, Lim SW, Ahn KO, Yang JH, Choi YH, Yoon KH, Sugawara A, Ito S, Kim J, and Yang CW. Rosiglitazone protects against cyclosporine-induced pancreatic and renal injury in rats. Am J Transplant 5: 1856-1867, 2005.

13. Cong Y, Brandwein SL, McCabe RP, Lazenby A, Birkenmeier EH, Sundberg JP, and Elson CO. CD4+ T cells reactive to enteric bacterial antigens in spontaneously colitic $\mathrm{C} 3 \mathrm{H} / \mathrm{HeJBir}$ mice: increased $\mathrm{T}$ helper cell type 1 response and ability to transfer disease. J Exp Med 187: 855-864, 1998.

749 skin irritation induced by tributyltin by increasing nuclear factor kappa B activation. J Invest Dermatol 117: 1627-1634, 2001. 
751 15. Diehl AM, Li ZP, Lin HZ, and Yang SQ. Cytokines and the pathogenesis of

752 non-alcoholic steatohepatitis. Gut 54: 303-306, 2005.

753 16. Eksteen B, Miles AE, Grant AJ, and Adams DH. Lymphocyte homing in the 754 pathogenesis of extra-intestinal manifestations of inflammatory bowel disease.

755 Clin Med 4: 173-180, 2004.

756 17. Farrant JM, Hayllar KM, Wilkinson ML, Karani J, Portmann BC, Westaby D, 757 and Williams R. Natural history and prognostic variables in primary sclerosing 758 cholangitis. Gastroenterology 100: 1710-1717, 1991.

759 18. Flanagan DL, Gross R, Jennings CD, Caywood BE, Goes S, Kaplan AM, and 760 Bryson JS. Induction of syngeneic graft-versus-host disease in LPS

761 hyporesponsive C3H/HeJ mice. J Leukoc Biol 70: 873-880, 2001.

762 19. Flanagan DL, Jennings CD, and Bryson JS. Th1 cytokines and NK cells 763 participate in the development of murine syngeneic graft-versus-host disease. $J$ 764 Immunol 163: 1170-1177, 1999.

765 20. Fujino S, Andoh A, Bamba S, Ogawa A, Hata K, Araki Y, Bamba T, and 766 Fujiyama Y. Increased expression of interleukin 17 in inflammatory bowel 767 disease. Gut 52: 65-70, 2003.

768 21. Giulietti A, Overbergh L, Valckx D, Decallonne B, Bouillon R, and Mathieu 769 C. An overview of real-time quantitative PCR: applications to quantify cytokine 770 gene expression. Methods 25: 386-401, 2001.

771 22. Harada K, Shimoda S, Sato Y, Isse K, Ikeda H, and Nakanuma Y. Periductal 772 interleukin-17 production in association with biliary innate immunity contributes 773 to the pathogenesis of cholangiopathy in primary biliary cirrhosis. Clin Exp 774 Immunol 157: 261-270, 2009. 
23. Harrington LE, Mangan PR, and Weaver CT. Expanding the effector CD4 Tcell repertoire: the Th17 lineage. Curr Opin Immunol 18: 349-356, 2006.

24. Hess AD, and Thoburn CJ. Immune tolerance to self-major histocompatibility complex class II antigens after bone marrow transplantation: role of regulatory T cells. Biol Blood Marrow Transplant 12: 518-529, 2006.

25. Hill GR, Crawford JM, Cooke KR, Brinson YS, Pan L, and Ferrara JL. Total body irradiation and acute graft-versus-host disease: the role of gastrointestinal damage and inflammatory cytokines. Blood 90: 3204-3213, 1997.

26. Hillan KJ, Hagler KE, MacSween RN, Ryan AM, Renz ME, Chiu HH, Ferrier RK, Bird GL, Dhillon AP, Ferrell LD, and Fong S. Expression of the mucosal vascular addressin, MAdCAM-1, in inflammatory liver disease. Liver 19: 509-518, 1999.

27. Holtta V, Klemetti P, Sipponen T, Westerholm-Ormio M, Kociubinski G, Salo H, Rasanen L, Kolho KL, Farkkila M, Savilahti E, and Vaarala O. IL-23/IL-17 immunity as a hallmark of Crohn's disease. Inflamm Bowel Dis 14: 1175-1184, 2008.

28. Iwasaki A, and Medzhitov R. Toll-like receptor control of the adaptive immune responses. Nat Immunol 5: 987-995, 2004.

29. Kim HJ, Hwang SJ, Kim BK, Jung KC, and Chung DH. NKT cells play critical roles in the induction of oral tolerance by inducing regulatory $\mathrm{T}$ cells producing IL-10 and transforming growth factor beta, and by clonally deleting antigen-specific T cells. Immunology 118: 101-111, 2006.

30. Knight C, and Murray KF. Hepatobiliary associations with inflammatory bowel disease. Expert Rev Gastroenterol Hepatol 3: 681-691, 2009. 
31. Kronenberg M, and Gapin L. The unconventional lifestyle of NKT cells. Nat Rev Immunol 2: 557-568, 2002.

32. Lafdil F, Wang H, Park O, Zhang W, Moritoki Y, Yin S, Fu XY, Gershwin ME, regulating T helper 1 cytokine and interleukin-17 production. Gastroenterology 137: 2125-2135 e2121-2122, 2009.

33. Lan RY, Salunga TL, Tsuneyama K, Lian ZX, Yang GX, Hsu W, Moritoki Y, Ansari AA, Kemper C, Price J, Atkinson JP, Coppel RL, and Gershwin ME. Hepatic IL-17 responses in human and murine primary biliary cirrhosis. J Autoimmun 32: 43-51, 2009.

34. LaSpina M, Tripathi S, Gatto LA, Bruch D, Maier KG, and Kittur DS. An interleukin-6-neutralizing antibody prevents cyclosporine-induced nephrotoxicity

811 in mice. J Surg Res 148: 121-125, 2008.

812 35. Lichtman SN, Keku J, Clark RL, Schwab JH, and Sartor RB. Biliary tract disease in rats with experimental small bowel bacterial overgrowth. Hepatology 13: 766-772, 1991.

36. Lichtman SN, Wang J, and Clark RL. A microcholangiographic study of

$816 \quad$ liver disease models in rats. Acad Radiol 2: 515-521, 1995.

817 37. Lohr J, Knoechel B, Wang JJ, Villarino AV, and Abbas AK. Role of IL-17 and 818 regulatory T lymphocytes in a systemic autoimmune disease. J Exp Med 203:

$819 \quad 2785-2791,2006$.

38. Matsuda JL, Naidenko OV, Gapin L, Nakayama T, Taniguchi M, Wang CR,

821 Koezuka Y, and Kronenberg M. Tracking the response of natural killer T cells to a 822 glycolipid antigen using CD1d tetramers. J Exp Med 192: 741-754, 2000. 
39. Mendes FD, Levy C, Enders FB, Loftus EV, Jr., Angulo P, and Lindor KD. Abnormal hepatic biochemistries in patients with inflammatory bowel disease. The American journal of gastroenterology 102: 344-350, 2007.

40. Numata Y, Tazuma S, Nishioka T, Ueno Y, and Chayama K. Immune response in mouse experimental cholangitis associated with colitis induced by dextran sulfate sodium. J Gastroenterol Hepatol 19: 910-915, 2004.

41. Numata Y, Tazuma S, Ueno Y, Nishioka T, Hyogo H, and Chayama K. Therapeutic effect of repeated natural killer $\mathbf{T}$ cell stimulation in mouse cholangitis complicated by colitis. Dig Dis Sci 50: 1844-1851, 2005.

42. O'Mahony CA, and Vierling JM. Etiopathogenesis of primary sclerosing cholangitis. Semin Liver Dis 26: 3-21, 2006.

43. Orth T, Peters M, Schlaak JF, Krummenauer F, Wanitschke R, Mayet WJ, Galle PR, and Neurath MF. Mycophenolate mofetil versus azathioprine in patients with chronic active ulcerative colitis: a 12-month pilot study. The American journal of gastroenterology 95: 1201-1207., 2000.

44. Overbergh L, Valckx D, Waer M, and Mathieu C. Quantification of murine cytokine mRNAs using real time quantitative reverse transcriptase PCR. Cytokine 11: 305-312, 1999.

45. Rong G, Zhou Y, Xiong Y, Zhou L, Geng H, Jiang T, Zhu Y, Lu H, Zhang S, Wang $P$, Zhang $B$, and Zhong $R$. Imbalance between $T$ helper type 17 and $T$ regulatory cells in patients with primary biliary cirrhosis: the serum cytokine profile and peripheral cell population. Clin Exp Immunol 156: 217-225, 2009. 
46. Shlomai A, Trop S, Gotsman I, Jurim O, Diment J, Alper R, Rabbani E, Engelhardt D, and Ilan Y. Immunomodulation of experimental colitis: the role of NK1.1 liver lymphocytes and surrogate antigens--bystander effect. J Pathol 195: 498-507, 2001.

47. Sonoda KH, Exley M, Snapper S, Balk SP, and Stein-Streilein J. CD1reactive natural killer $\mathrm{T}$ cells are required for development of systemic tolerance through an immune-privileged site. J Exp Med 190: 1215-1226, 1999.

48. Strober W, Fuss I, and Mannon P. The fundamental basis of inflammatory bowel disease. J Clin Invest 117: 514-521, 2007.

49. Strober W, Fuss IJ, and Blumberg RS. The immunology of mucosal models of inflammation. Annu Rev Immunol 20: 495-549, 2002.

50. Talwalkar JA, and Lindor KD. Primary sclerosing cholangitis. Inflamm Bowel Dis 11: 62-72, 2005.

51. Tariq M, Morais C, Sobki S, Al Sulaiman M, and Al Khader A. Nacetylcysteine attenuates cyclosporin-induced nephrotoxicity in rats. Nephrol Dial Transplant 14: 923-929, 1999.

52. Terjung B, Soehne J, Lechtenberg B, Gottwein J, Muennich M, Herzog V, Maehler M, Sauerbruch T, and Spengler U. p-ANCA in Autoimmune Liver Disorders Recognize Human Beta-Tubulin Isotype 5 and Cross-react with Microbial Protein FtsZ. Gut 2009.

53. Terjung B, and Spengler U. Atypical p-ANCA in PSC and AlH: a hint toward a "leaky gut"? Clin Rev Allergy Immunol 36: 40-51, 2009.

54. Terjung B, and Spengler U. Role of auto-antibodies for the diagnosis of chronic cholestatic liver diseases. Clin Rev Allergy Immunol 28: 115-133, 2005. 
55. Toyonaga T, Hino O, Sugai S, Wakasugi S, Abe K, Shichiri M, and Yamamura K. Chronic active hepatitis in transgenic mice expressing interferongamma in the liver. Proc Natl Acad Sci U S A 91: 614-618, 1994.

56. Trop S, and Ilan Y. NK 1.1+ T cell: a two-faced lymphocyte in immune modulation of the IL-4/IFN-gamma paradigm. J Clin Immunol 22: 270-280, 2002.

57. Trop S, Samsonov D, Gotsman I, Alper R, Diment J, and Ilan Y. Liverassociated lymphocytes expressing NK1.1 are essential for oral immune tolerance induction in a murine model. Hepatology 29: 746-755, 1999.

58. Vierling JM, Ruderman WB, Jaffee BD, Fennell RH, Jr., and Claman HN. Hepatic lesions in murine chronic graft-versus-host disease to minor histocompatibility antigens. A reproducible model of nonsuppurative destructive cholangitis. Transplantation 48: 717-718, 1989.

59. Wakabayashi K, Lian ZX, Moritoki Y, Lan RY, Tsuneyama K, Chuang YH, Yang GX, Ridgway W, Ueno Y, Ansari AA, Coppel RL, Mackay IR, and Gershwin ME. IL-2 receptor alpha(-/-) mice and the development of primary biliary cirrhosis. Hepatology 44: 1240-1249, 2006.

60. Wolf A, Trendelenburg CF, Diez-Fernandez C, Prieto P, Houy S, Trommer WE, and Cordier A. Cyclosporine A-induced oxidative stress in rat hepatocytes. $J$ Pharmacol Exp Ther 280: 1328-1334, 1997.

61. Worthington J, Cullen S, and Chapman R. Immunopathogenesis of primary sclerosing cholangitis. Clin Rev Allergy Immunol 28: 93-103, 2005. 
62. Wu DY, and Goldschneider I. Cyclosporin A-induced autologous graftversus-host disease: a prototypical model of autoimmunity and active (dominant)

895 tolerance coordinately induced by recent thymic emigrants. $J$ Immunol 162: 6926896 6933., 1999.

897 63. Xun CQ, Thompson JS, Jennings CD, Brown SA, and Widmer MB. Effect of 898 total body irradiation, busulfan-cyclophosphamide, or cyclophosphamide 899 conditioning on inflammatory cytokine release and development of acute and 900 chronic graft-versus-host disease in H-2-incompatible transplanted SCID mice. 901 Blood 83: 2360-2367, 1994.

902 64. Zhou D, Brown SA, Yu T, Chen G, Barve S, Kang BC, and Thompson JS. A 903 high dose of ionizing radiation induces tissue-specific activation of nuclear 904 factor-kappaB in vivo. Radiat Res 151: 703-709, 1999. 


\section{FIGURES}

Figure 1.

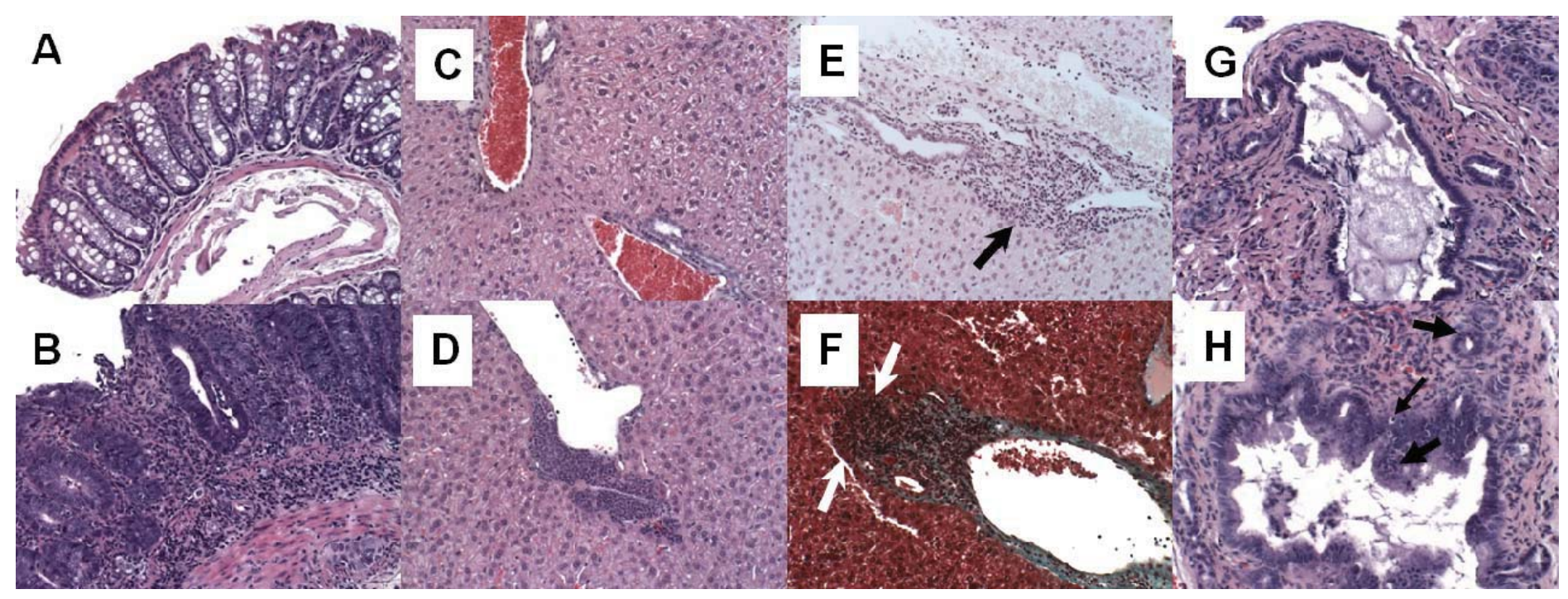


Figure 2

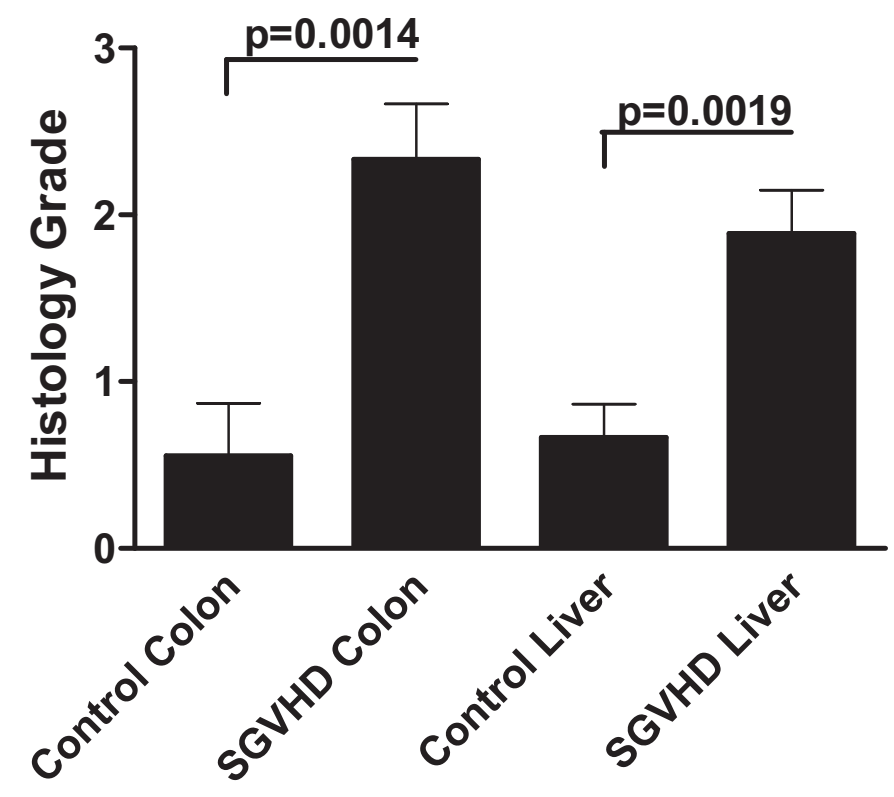


Figure 3.
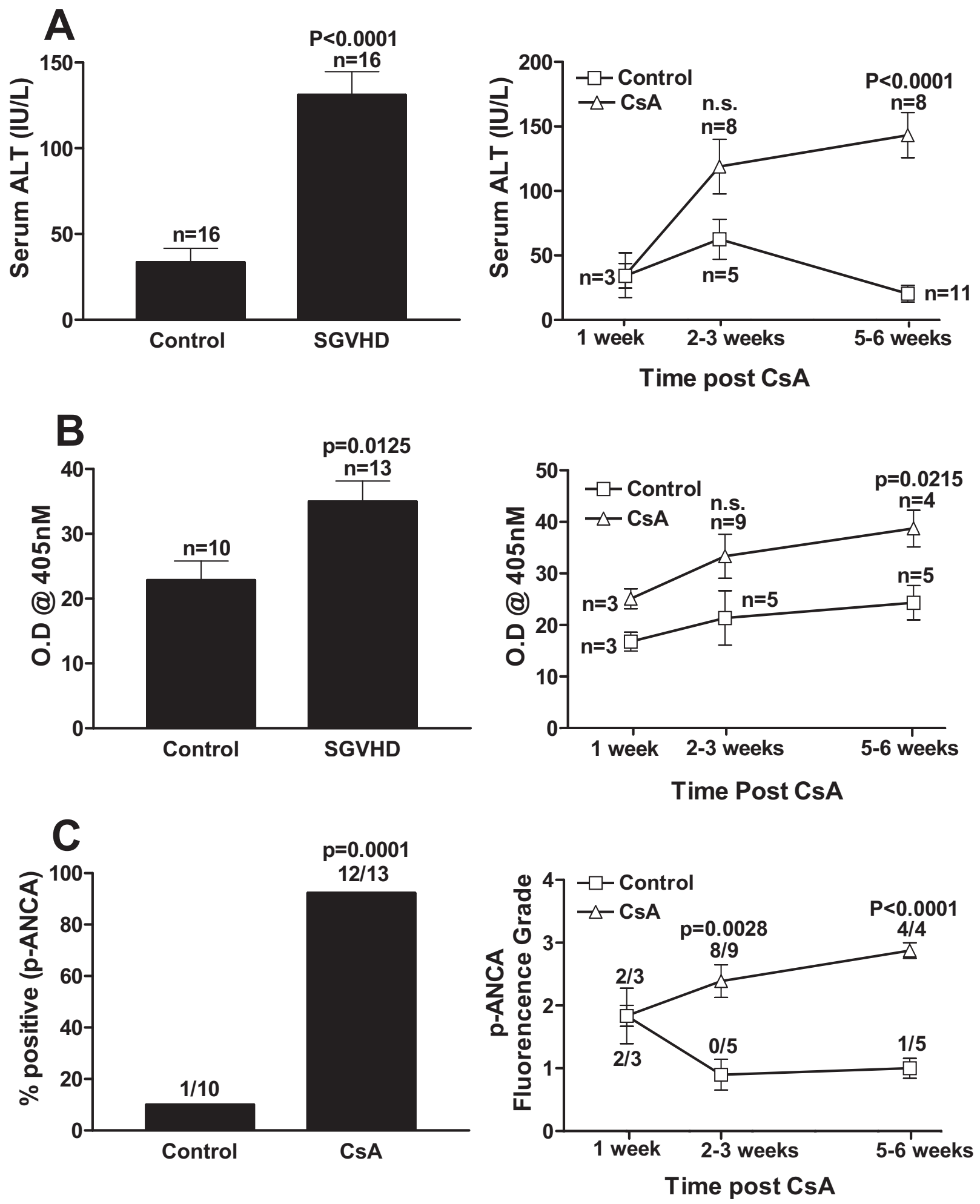
Figure 4
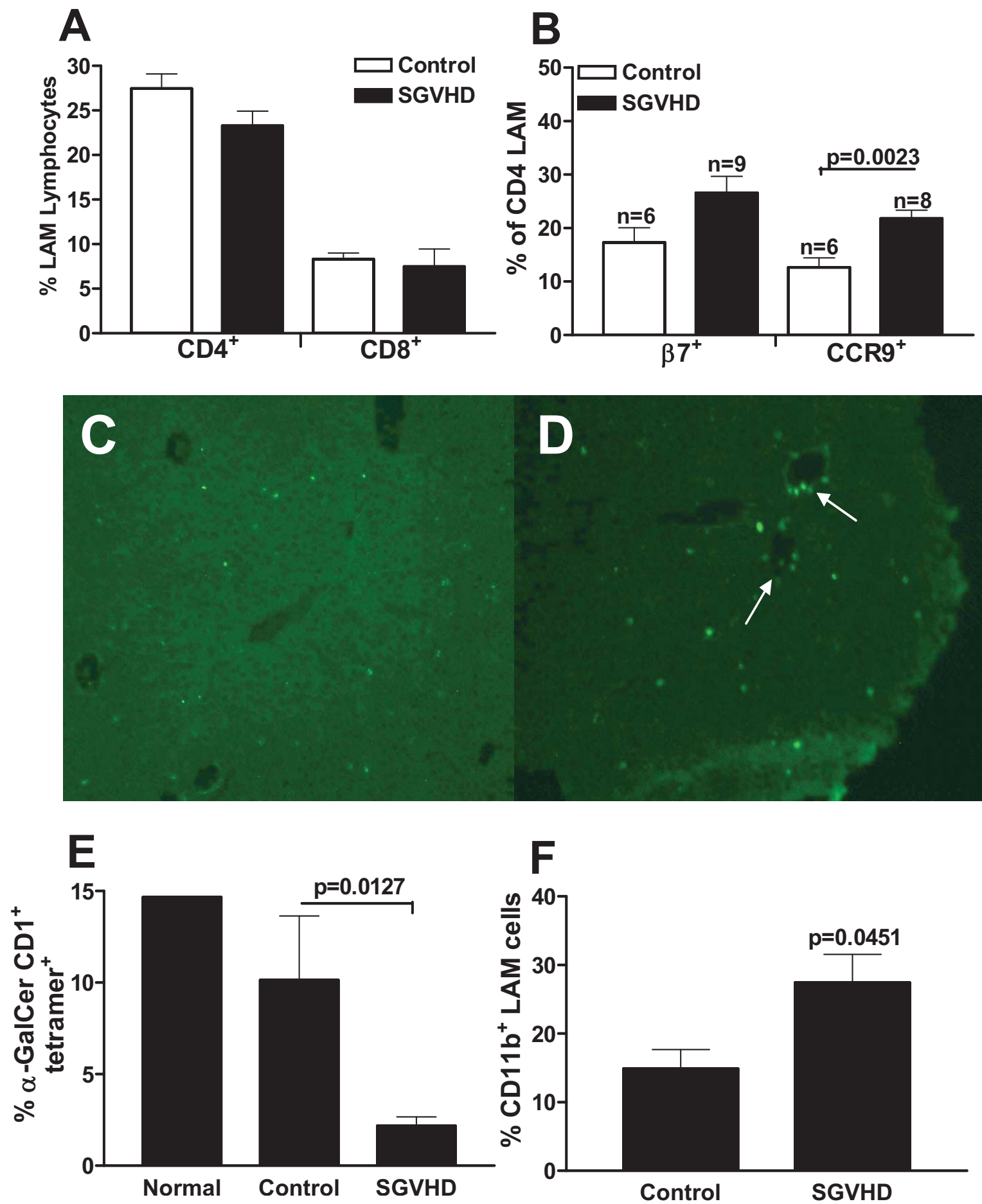
Figure 5

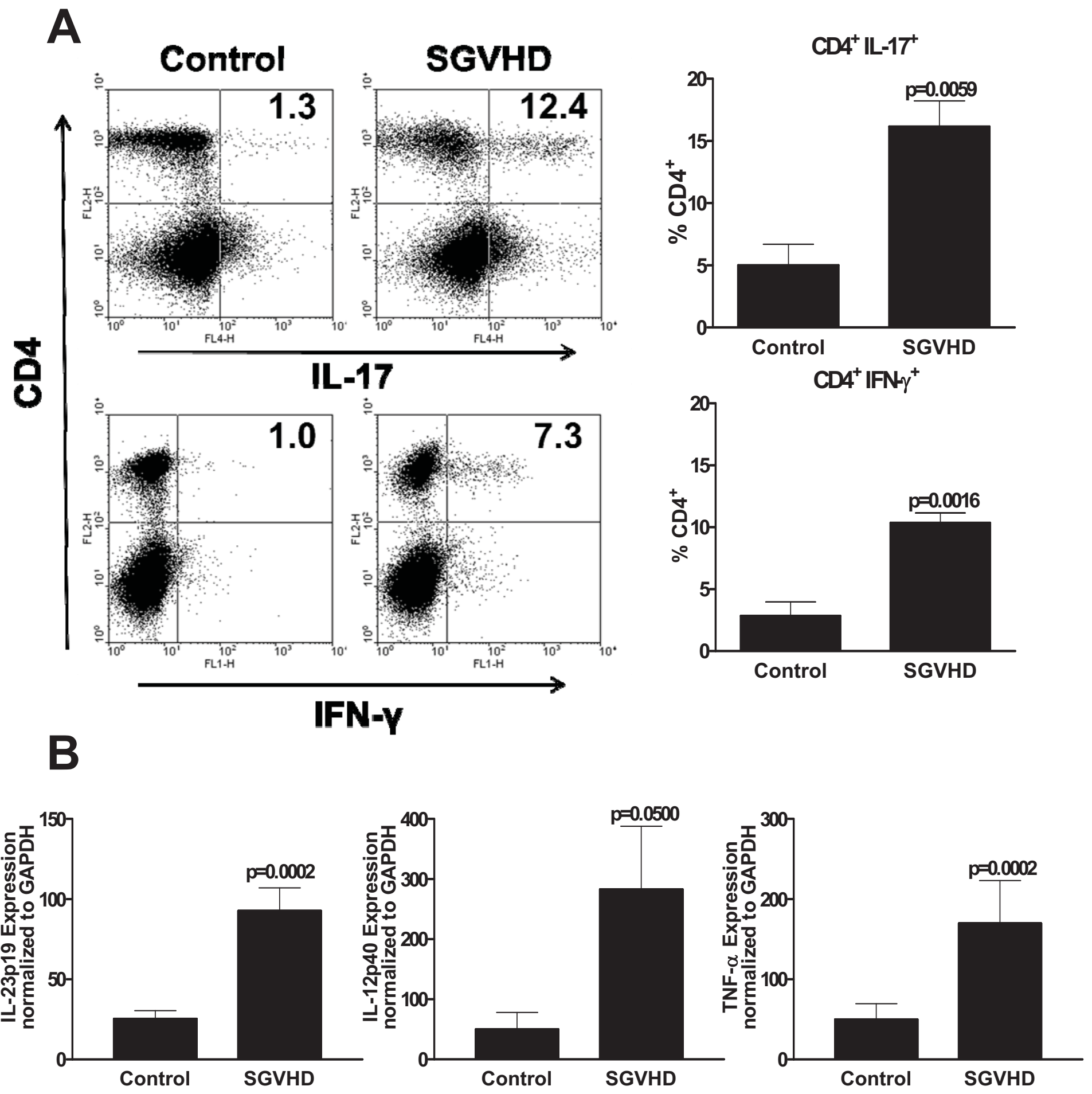


Figure 6
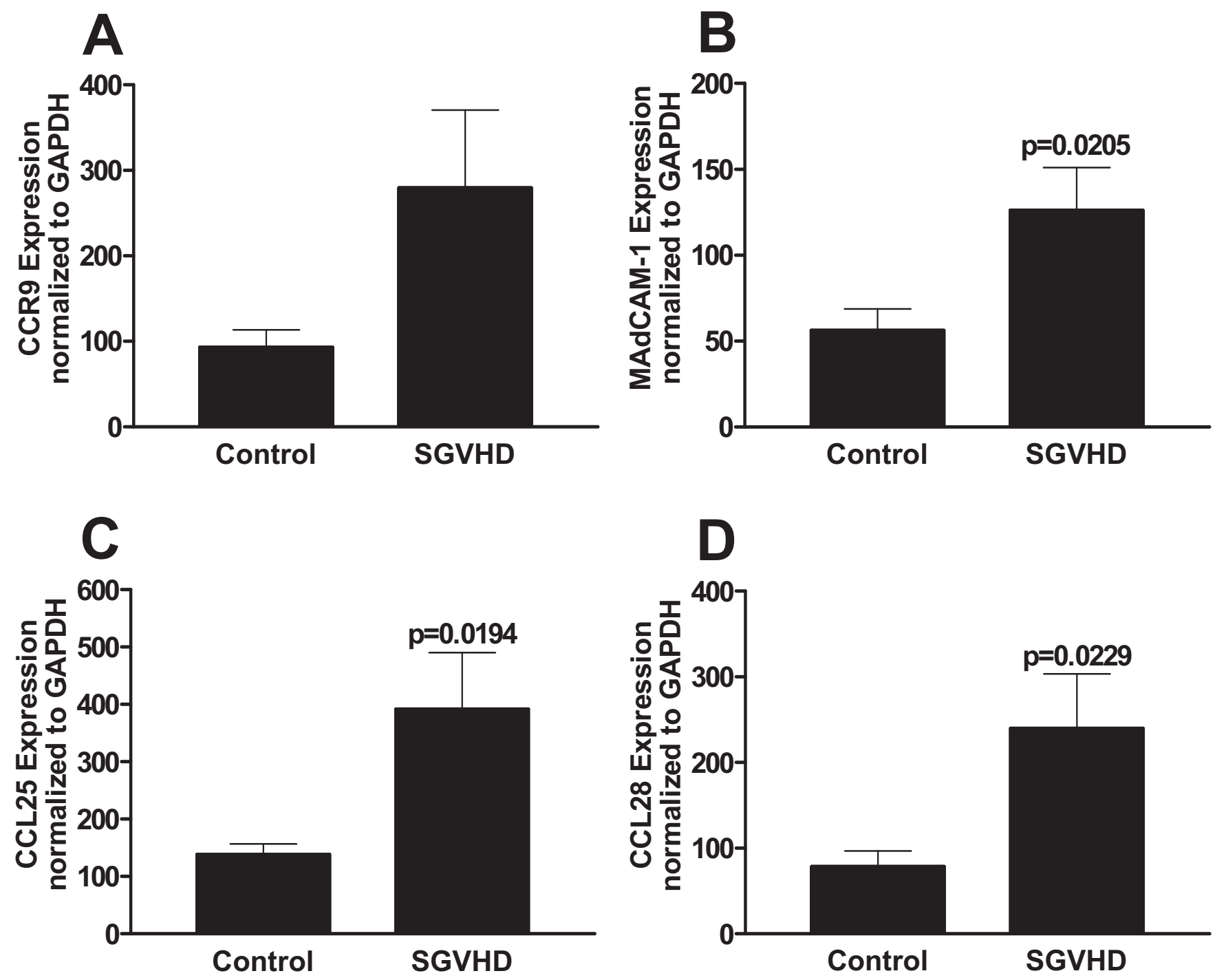
Figure 7

A
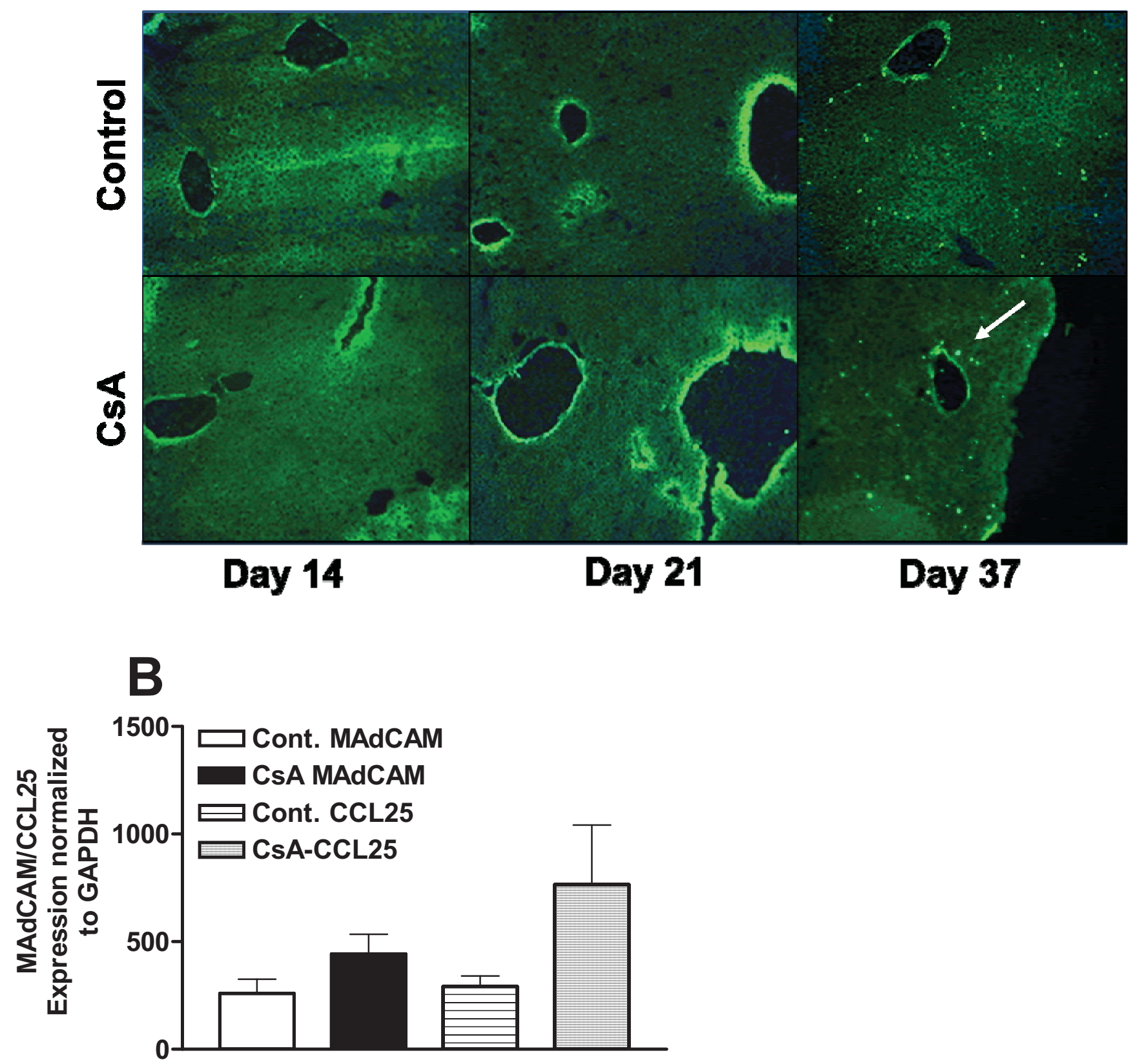
Figure 8.

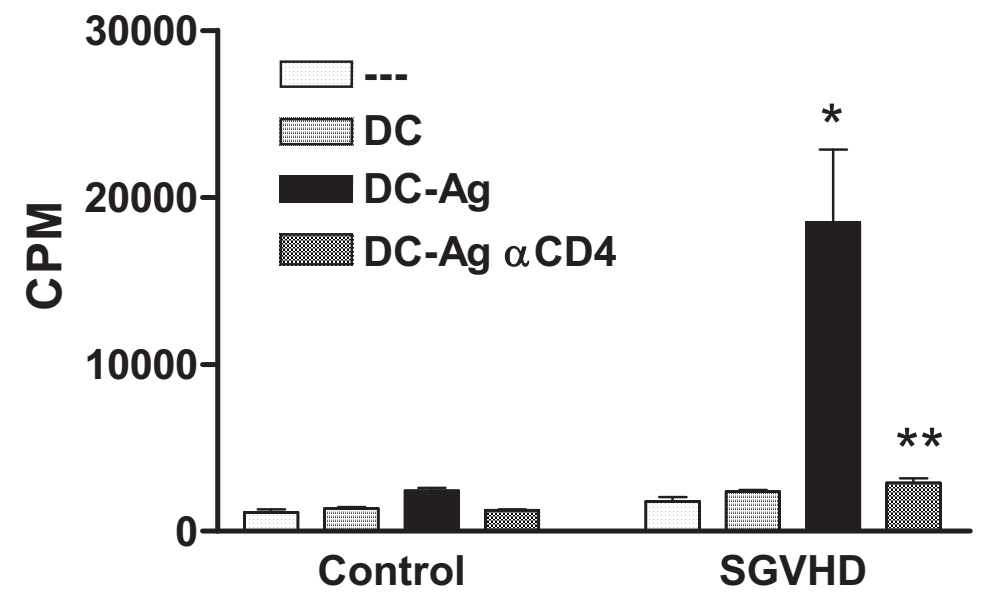


Supplemental Figure 1
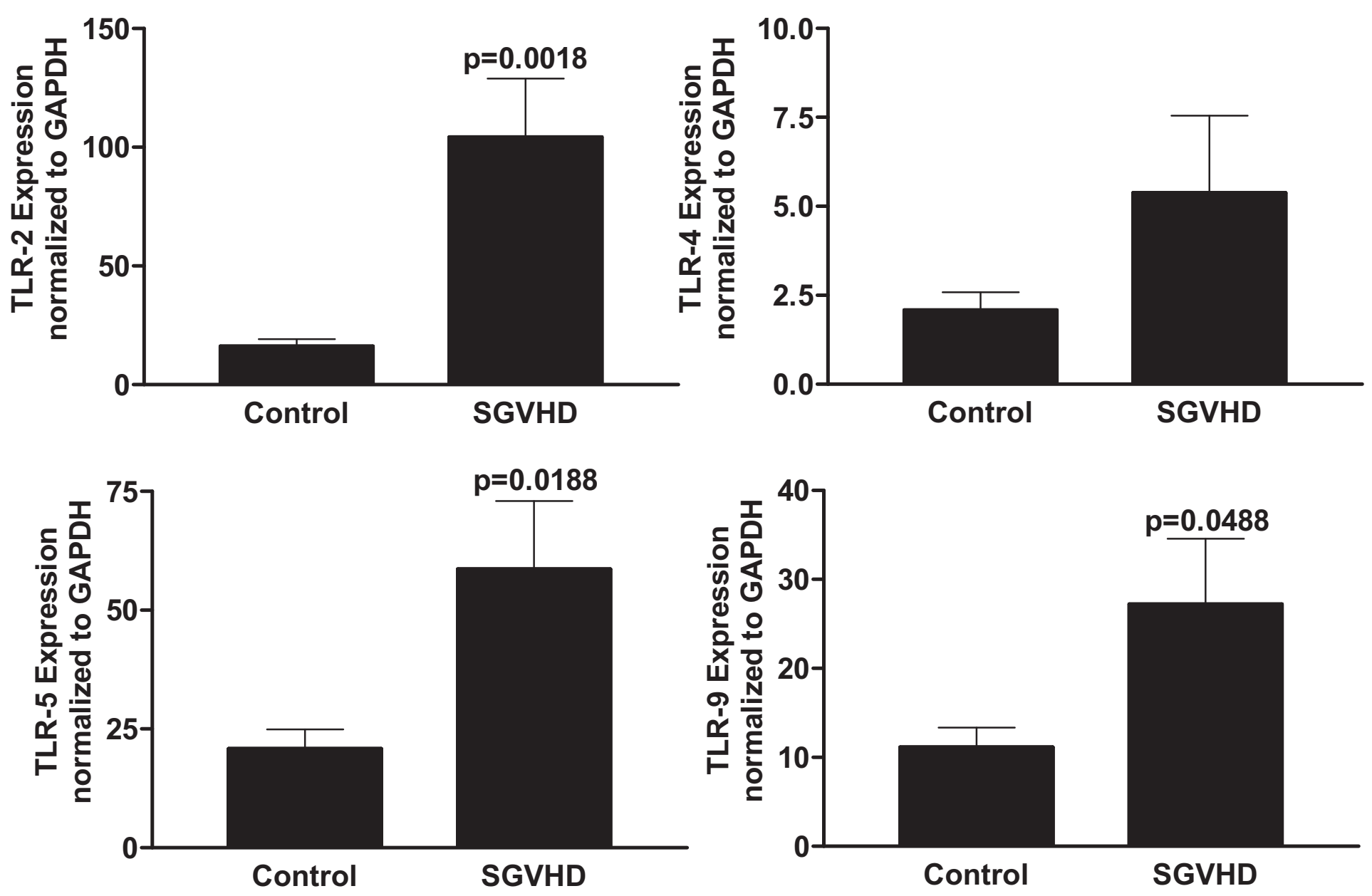
Supplemental Figure 2.
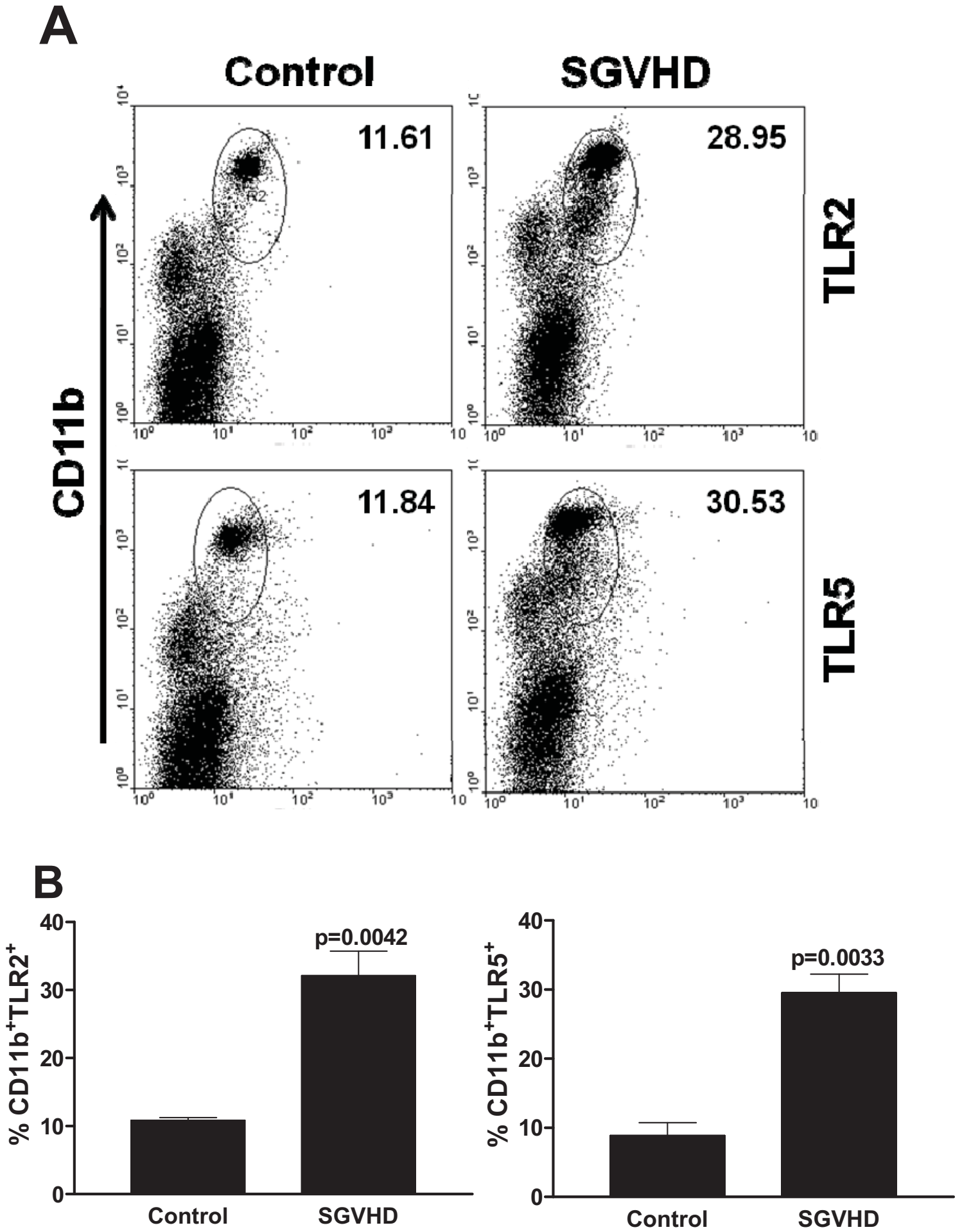